\title{
MACRO- AND MICROMORPHOLOGICAL STUDY OF THE LEAF, STEM AND INFLORESCENCE OF ERANTHEMUM NERVOSUM T. ANDERS (FAM. ACANTHACEAE), CULTIVATED IN EGYPT
}

Mahmoud H. Assaf ${ }^{1}$, Yaser G. Gouda ${ }^{1}$, Ehab S. El-Khayat ${ }^{2}$ and Reda A. Abd El-Hamid ${ }^{2}$

${ }^{1}$ Department of Pharmacognosy, Faculty of Pharmacy, Assiut University, Assiut, Egypt

${ }^{2}$ Department of Pharmacognosy, Faculty of Pharmacy, Al-Azhar University, Assiut, Egypt

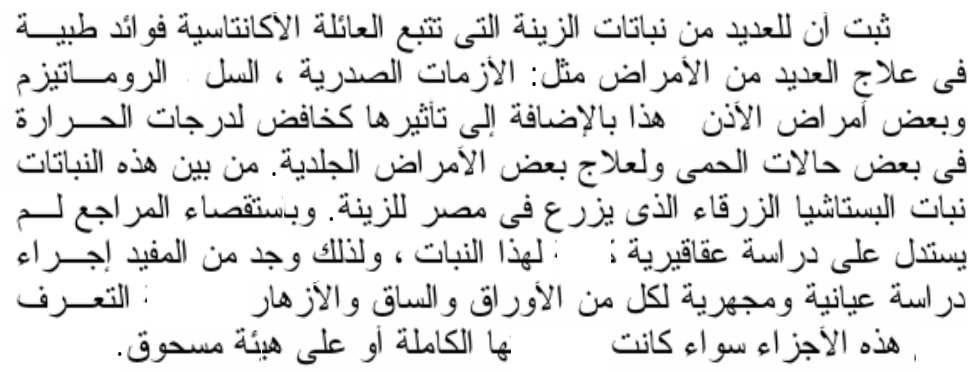

Many ornamental plants belonging to the family Acanthaceae, showed interesting medicinal activities in treating: cough, chronic bronchitis, rheumatism, jaundice, ear troubles and fever. In addition to treatment of some skin diseases. In the present work, the detailed macro- and micromorphological characters of the leaf, stem and inflorescence of Eranthemum nervosum T. Anders family Acanthaceae, were studied with the aim to find out the diagnostic elements of these organs, which facilitate their identification in both entire and powdered forms.

\section{INTRODUCTION}

Family Acanthaceae is one of richest families with medicinal plants, comprising about 250 genera and 2500 species, distributed in tropics, Mediterranean regions, Australia, Central America, Brazil, Africa and 
Indo-Malaysia ${ }^{1-3}$. A bout 70 genera and 340 species have been reported from India ${ }^{1}$. The plants belonging to this family are perennial armed or unarmed herbs or shrubs, rarely trees; some are lianes, xerophytes, aquatics or mesophytes ${ }^{2}$.

Family Acanthaceae is divided into four subfamilies; Nelsonioideae, Menoncioideae, Thunbergioideae and Acanthoideae. The subfamily Menoncioideae and Thunbergioideae are intermediate between the Acanthaceae and the Bignoniaceae and are sometimes considered as separate families. ${ }^{4}$. The genus Eranthemum contains 14 species; the widely distributed and known members are Eranthemum laxiflorum, E. tuberculatum, E. reticulatum, E. andersonii, $E$. nervosum and $E$. roseus 5 .

Plants of the genus Eranthemum are perennial tropical herbs, shrubs or sub-shrubs, with blue or rosecoloured flowers, some of which are cultivated for their foliage and others for their flowers. Eranthemum nervosum T. Anders ${ }^{5}$, cultivated in Egypt, is one of these ornamentals. On reviewing current literature no pharmacological study for this plant could be traced. Chemical investtigation of this plant identified one iridoid (Eranthemoside) ${ }^{6}$ and one alkaloid (3-Methoxy vasicinone) ${ }^{7}$.
Preliminary phytochemical screening of the title plant revealed the prescence of sterols, triterpenes, flavonoids, iridoids and alkaloids. This prompted us to undertake a pharmacognostical investigation of the plant. The present work deals with the macro- and micromorphology of the leaf, stem and inflorescence of the plant in both entire and powdered forms.

\section{Plant material}

The different organs were collected in the period from April to July 2004 from the Experimental Station of Faculty of Agriculture, Assiut University. The plant was identified by Prof. Dr. Naeim Elkeltawy, Department of Horticulture, Faculty of Agriculture, Assiut University. Fresh samples were preserved in a mixture of $70 \%$ alcohol - glycerin - water (1:1:1) until used. For studying the powder, the leaves, stem and Inflorescence were air-dried, reduced to powder and kept for microscopical investigation.

\section{Habitat}

Eranthemum nervosum T. Anders (Fig. 1) is a perennial herb measuring $0.5-2 \mathrm{~m}$ in height, with an erect stem. The leaves are ovate to ovate lanceolate. The flowers are perfect arranged in terminal or axillary and opposite raceme spike inflorescence measuring $3-10 \mathrm{~cm}$ in length. 


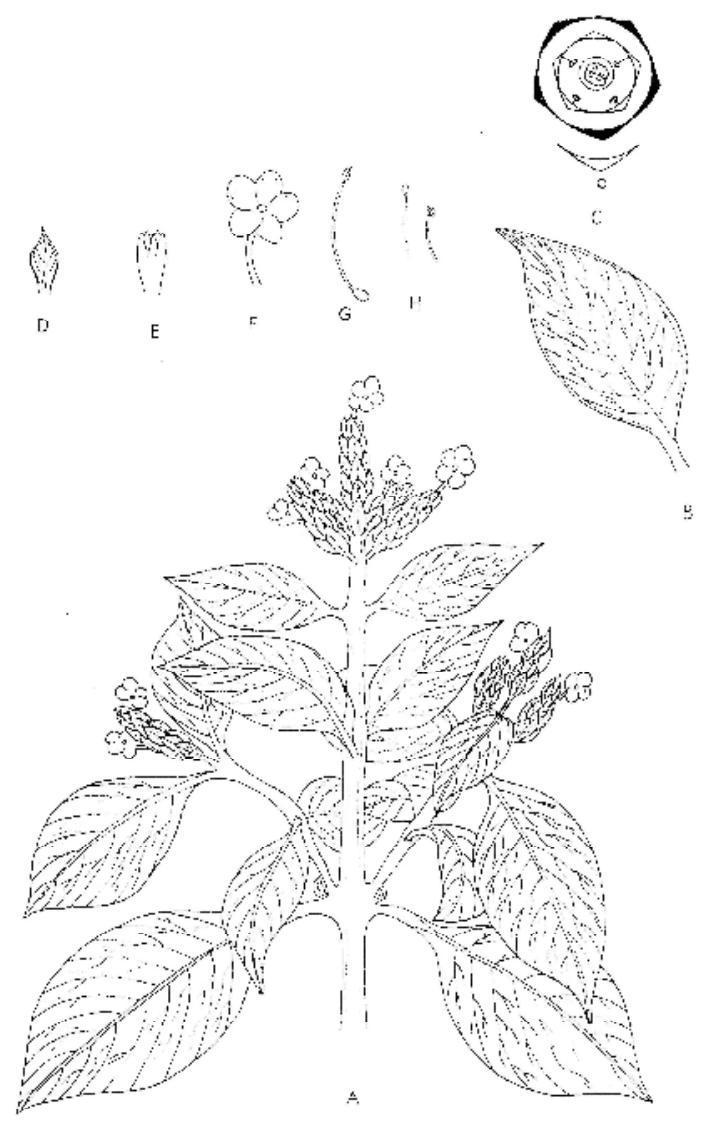

Fig. 1: Macromorphology of the leaf, stem and inflorescences
a) Morphology of the aerial parts
(x 0.18$)$
b) Morphology of the leaf
(x 0.18$)$
c) Floral diagram
d) Morphology of the bract
(x 0.34$)$
e) Morphology of the calyx
$(\mathrm{x} 0.86)$
f) Morphology of the corolla
$(\mathrm{x} 0.34)$
g) Morphology of the gynaecium
$(\mathrm{x} 0.86)$
h) Morphology of the androecium
(x 0.86) 


\section{THE LEAF}

\section{Macromorphology}

The leaves (Fig. 1A\&B) are simple, exstipulate, ovate to lanceolate in shape with entire margins, decurrent bases and acuminate apices being arranged in an opposite decussate manner, and with pinnate-reticulate vennation. They range from $8-18 \mathrm{~cm}$ in length and from $4-9 \mathrm{~cm}$ in width. The upper surface of the leaf is dark green in colour while the lower one being paler. Hairs are often present on the midrib and rare on the lamina. The petiole is nearly cylindrical in outline, green in colour, hairy and showing a slight groove on the upper side. The petiole is short in the upper leaves and long in the lower ones, measuring from $0.8-2.5 \mathrm{~cm}$ in length and from $0.3-0.6 \mathrm{~mm}$ in diameter. The dried leaves are brittle in texture with faint odour and slight bitter taste.

\section{Micromorphology of the lamina}

A transverse section in the leaf (Fig. 2A\&B) shows upper and lower epidermises and prominent midrib on the lower surface, with a dorsiventral structure, cortical tissues and vascular strands. The upper and lower epidermises carry glandular and nonglandular hairs and numerous cystoliths. Numerous raphides of calcium oxalate as well as starch granules are scattered in the mesophyll and cortical tissues.

\section{Upper epidermis}

The upper epidermis (Fig. 2C) is formed of subrectangular cells covered with thin cuticle measuring 11-13-23 in height. In surface view (Fig. 4), the cells appear polygonal in shape, with slightly wavy anticlinal walls and covered with smooth cuticle, some cells are papillosed, measuring 41-48-62 in length and $20-25 \quad-33$ in width. The neural epidermal cells, (Fig. 4) are rectangular, axially-elongated with straight anticlinal walls. They measure 15-24-39 in length and 814-24 in width. Stomata are rare, mostly of diacytic type, usually oval to rounded in shape measuring 14-2024 in diameter. Glandular and nonglandular hairs are numerous in the midrib region, but rare in the lamina. The nonglandular hairs are of many types (Fig. 4) some being unicellular, covered with warty cuticle, sometimes with curved base, measuring 11-20-45 in length and 4-5-6 in width at the middle. Another type is multicellular uniseriate ranging from 2-6 cells covered with warty cuticle, measuring 57- $\underline{88-234}$ in length and 11-13-17 in width. In addition, multicellular nonglandular hairs are present, almost (3) cells, slightly enlarged in the middle part and covered with warty cuticle, measuring 48-50-51 in length and 13-14-16 in width. Bicellular nonglandular hairs are present, covered with smooth cuticle, the apical cell occasionally covered with warty cuticle, measuring 24-3034 in length and (6-7-7 ) in width.

The glandular hairs consist of unicellular stalk and multicellular head composed of four radiating 
cells, measuring 23-24-27 in diameter. Numerous cells of the epidermis are modified to cystoliths containing deposits of calcium carbonate (Figs. 2C\&4) which dissolve in dil. $\mathrm{HCl}$ with effervescence, the occurrence of these cystoliths is reported as one of the most characteristic features of family Acanthaceae ${ }^{8}$.

\section{Lower epidermis}

The lower epidermis (Fig. 2C) is similar in structure to the upper one. In surface view (Fig. 4), the cells are polygonal, with wavy anticlinal walls and covered with smooth cuticle, measuring 33-51-60 in length, 15$\underline{20-28}$ in width, and 14- $\underline{15}-25$ in height. Both glandular and nonglandular hairs, as well as diacytic stomata are present, being similar to those of the upper epidermis but are greater in number.

\section{Mesophyll}

The mesophyll (Figs. 2B\&4) is dorsiventral, being differentiated into palisade and spongy tissue. The palisade is formed of one row of more or less compact, columnar cells; measuring 28-34-51 in length and 7-9-13 in width. The palisade cells (Fig. 2C) are continuous in the midrib region under the collenchyma cells. The spongy tissue (Figs. 2B\&4) is formed of thin-walled, rounded, or slightly oval chlorenchymatous cells with wide intercellular spaces containing simple rounded to oval, starch granules, measuring 17-21-30 in diameter and rarely compound granules of 2-4 components.

\section{Cortical tissue}

The cortical tissue of the midrib region (Fig. 2A\&C) is represented by subepidermal collenchymatous cellulosic cells, formed of 4-5 rows of nearly rounded cells with angular thickening, measuring 7-13-23 in diameter, some of which are modified to cystoliths containing deposits of calcium carbonate measuring 10-1417 in diameter. The upper collenchyma is followed by a single row of columnar palisade cells, measuring 20-23-25 in length and $7-\underline{8}-10$ in width. The ground tissue is formed of about 14-18 rows of thin-walled rounded to oval parenchymatous cells, measuring 1444-60 in diameter, some of which containing rounded to oval small starch granules, or acicular crystals of calcium oxalate measuring 3-4-6 in length. Some cells are modified to cystoliths containing deposits of calcium carbonate and measuring 1720-23 in diameter.

\section{Vascular system}

The vascular system in the midrib region (Fig. 2A\&C) is represented by a crescent-shape vascular tissue, with the xylem to the upper side and the phloem to the lower, and four additional smaller lateral vascular bundles usually present towards the upper surface. 


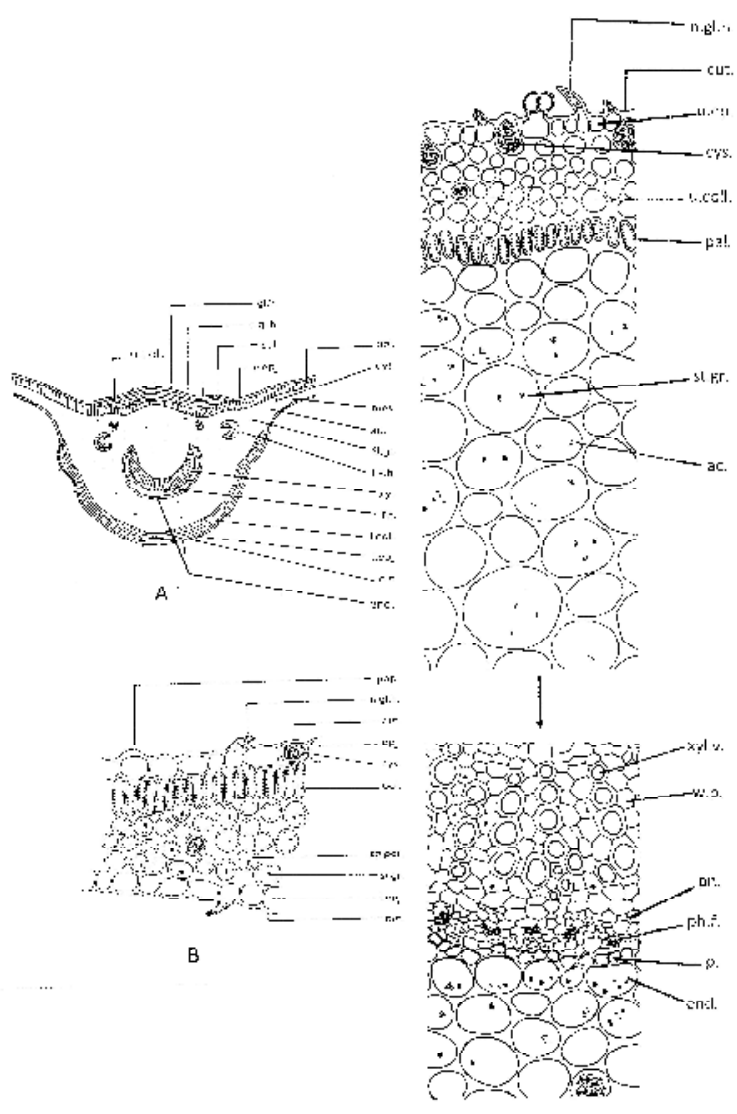

Fig. 2: Micromorphology of the leaf

A) T.S. Diagram of the leaf

B) Detailed T.S. sector in the lamina

C) Detailed T.S. sector in the midrib region

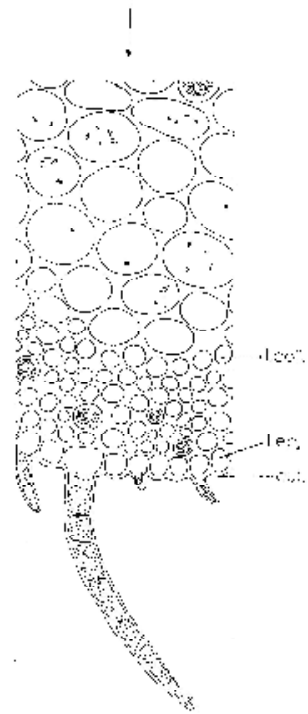

(x 13)

(x 157)

ac., acicular crystals of calcium oxalate; cut., cuticle; cys., cystoliths of calcium carbonate; end., endodermis; gl.h., glandular hair; l.coll., lower collenchyma; l.ep., lower epidermis; l.v.b., lateral vascular bundles; mes., mesophyll; n.gl.h., nonglandular hair; pal., palisade; pap., papilla; p., pericycle; ph., phloem; ph.f., phloem fibers; sp.par., spongy parenchyma; st.gr., starch granules; u.coll., upper collenchyma; u.ep., upper epidermis; w.p., wood parenchyma; xyl., xylem; xyl.v., xylem vessel. 


\section{Xylem}

The xylem (Figs. 2C\&4) is formed of lignified vessels and wood parenchyma. The vessels have pitted, spiral and sclariform thickening, measuring about 13-23-27 in diameter. The wood parenchyma cells are polygonal to subrectangular, with thin walls; measuring about 3-11-17 in width. The cambium is indistinct.

\section{Phloem}

The phloem, (Fig. 2C) is formed of small, thin-walled, cellulosic cells, poorly differentiated into sieve tubes, companion cells, and phloem parenchyma. Few scattered phloem fibers (Fig. 4) are also present with moderately thick, lignified walls, comparatively narrow lumine and acute to rounded apices, measuring 357-431-542 in length and 5-10-14 in width. The pericycle is formed of small thin-walled cells.

The lateral vascular bundles consists of xylem and phloem which similar in structure to the main vascular bundles while the endodermis is indistinct.

\section{Endodermis}

It is formed of one row of tangentially elongated thin-walled cells, containing starch granules. The endodermis is followed by a zone of parenchyma cells of the cortical tissue, about 6-8 rows with narrow intercellular spaces.

\section{Micromorphology of the petiole}

A transverse section in the petiole (Fig. 3A\&B) appears plano-convex in outline in the apical part with two projecting arms, but appears as a crescent shape without the arms in the distal part.

The petiole shows an upper epidermis covered with thin cuticle, followed by a layer of collenchyma cells, followed by a comparatively wide parenchymatous cortical tissue. The vascular system is formed of large, collateral, crescent-shaped vascular bundles surrounded by endodermis containing starch granules forming a starch sheath which are more distinct on the lower side in addition to four subsidiary smaller lateral vascular bundles usually present towards the upper surface. Numerous cystoliths of calcium carbonate are observed in the epidermal cells, as well as in the cortical region, resembling those of the lamina.

\section{Epidermis}

The epidermis (Fig. 3B) is formed of isodiametric to sub-rectangular cells measuring 19-21-23 in height, polygonal, almost elongated in shape with straight anticlinal walls in surface view (Fig. 4), measuring 22$\underline{35-48}$ in length and 14-17-27 in width. The epidermal cells are covered with thin cuticle and having diacytic stomata, cystoliths, glandular and nonglandular hairs similar to those of the lamina.

\section{Cortical tissue}

The outer layer of the cortical tissue (Figs. 3B\&4) is formed of 3-5 rows of rounded to oval collenchymatous cells. The remaining part is formed of 12-20 rows of 


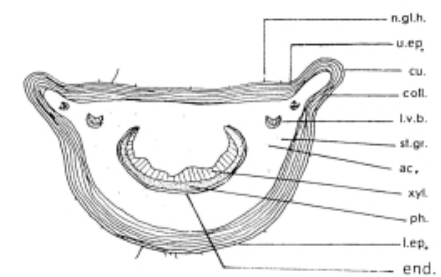

A
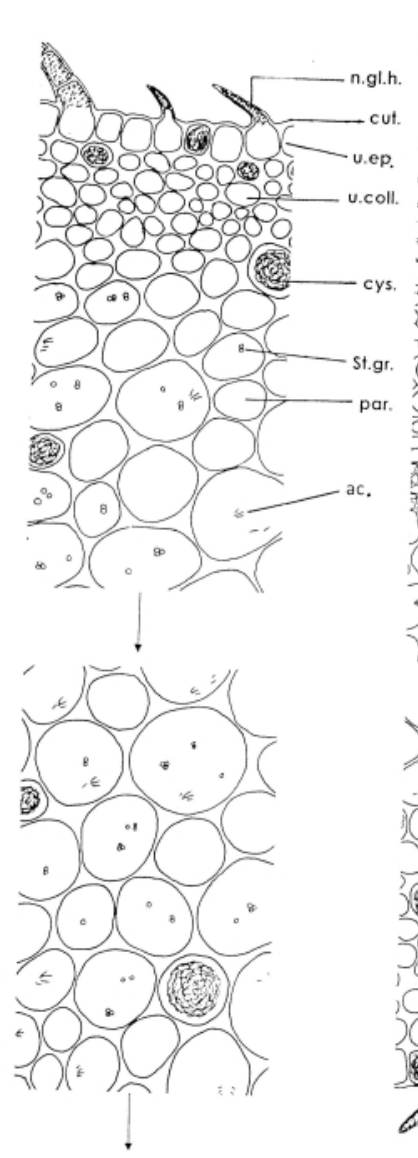
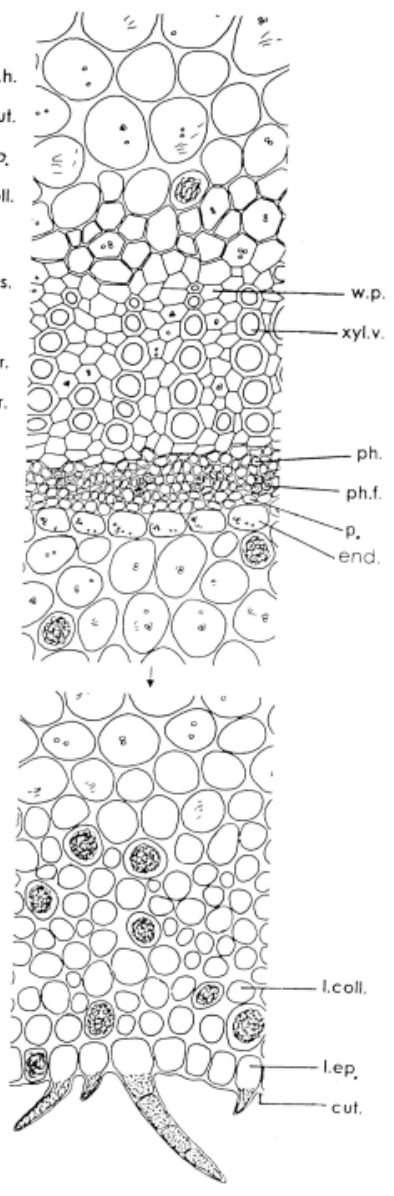

B

Fig. 3: Micromorphology of the petiole
A) T.S. Diagram of the petiole
(x 15.1)
B) Detailed T.S. sector of the petiole
(x 185)

ac., acicular crystals of calcium oxalate; coll., collenchyma; cut., cuticle; cys., cystoliths of calcium carbonate; end., endodermis; 1.coll. lower collenchyma; 1.ep., lower epidermis; l.v.b., lateral vascular bundles; n.gl.h., nonglandular hair; par., parenchyma; p., pericycle; ph., phloem; ph.f., phloem fibers; st.gr., starch granules; u.coll., upper collenchyma; u.ep., upper epidermis; w.p., wood parenchyma; xyl., xylem; xyl.v., xylem vessel. 
rounded to oval parenchyma cells with wide intercellular spaces, increasing gradually in size towards the inside and measuring 15-37-78 in diameter. Some cells are modified to cystoliths containing deposits of calcium carbonate. Acicular crystals of calcium oxalates are present in most parenchyma cells adjacent to the vascular bundle; being more abundant than in those away from the vascular bundle. Small compound starch granules (2-4 components), oval in shape with indistinct hilum and striations are present.

\section{Endodermis}

The endodermis (Fig. 3B) is formed of one row of tangentially elongated thin-walled cells, containing starch granules forming a starch sheath.

\section{Vascular system}

The vascular system (Figs. 3B\&4) is formed of large collateral cresentshaped vascular bundles. The phloem is formed of small, thin-walled, shining cellulosic elements, with scattered phloem fibers, of moderate thickening, slightly lignified walls, comparatively narrow lumine and acute to rounded apices. The cambium is indistinct, while the xylem is formed of vessels, and wood parenchyma, which are polygonal subrectangular cells having thin walls and resembling those of the lamina. The vessels are lignified, with spiral, pitted, and sclariform thickening, measuring 11- $\underline{23}-25$ in diameter. The four lateral vascular bundles have similar structure to the main vascular bundle.
The pericycle (Fig. 3B) consists of one to two layers of thin-walled cells.

\section{The powdered leaf}

The powder of the leaf (Fig. 4) is pale green in colour, with faint odour and slightly bitter taste. It is characterized microscopically by the following:

1- Fragments of upper epidermis of the leaf consisting of polygonal cells with slightly wavy anticlinal walls, covered with smooth cuticle, containing cystoliths of calcium carbonate, and carrying glandular and nonglandular hairs. The stomata are diacytic and very rare.

2- Fragments of lower epidermis of the leaf consisting of polygonal cells with wavy anticlinal walls, covered with smooth cuticle, containing cystoliths of calcium carbonate, having numerous diacytic stomata and carrying glandular and nonglandular hairs.

3- Fragments of epidermal cells of the petiole, polygonal with straight anticlinal walls showing diacytic stomata and nonglandular hairs.

4- Some palisade and spongy parenchymatous cells, containing chloroplasts and starch granules.

5- Numerous nonglandular hairs, unicellular with thin walls and covered with warty cuticle, sometimes with curved base, and multicellular uniseriate 2-6 cells with thin wall, wide lumina, and covered with warty cuticle, in addition to glandular hairs of unicellular stalk and multicellular head. 

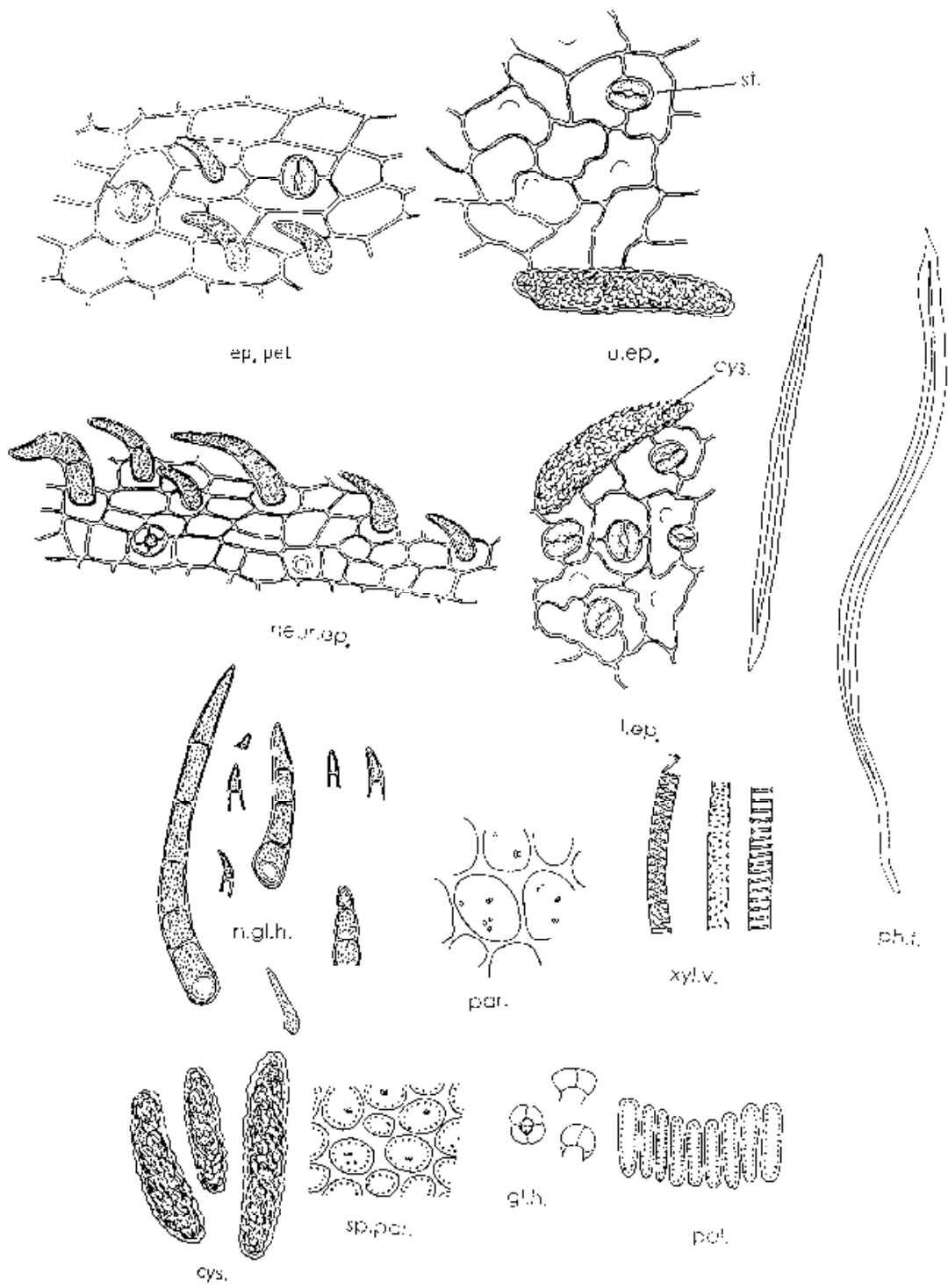

Fig. 4: Diagnostic elements of the powdered leaf

cys., cystoliths of calcium carbonate; ep.pet., epidermis of petiole; gl.h., glandular hair; l.ep., lower epidermis; n.gl.h., nonglandular hair; neur.ep., neural epidermal cells; pal., palisade; par., parenchyma; ph.f., phloem fibers; sp.par., spongy parenchyma; st., stomata; u.ep., upper epidermis; xyl.v., xylem vessel. 
6- Parenchyma cells showing numerous starch granules, as well as scattered acicular crystals of calcium oxalate.

7- Fragments of phloem fibers with moderately thick lignified walls moderately narrow lumina and acute to rounded apices.

8- Fragments of the neural epidermal cells, polygonal, subrectangular, axially elongated with straight anticlinal walls and carrying both glandular and nonglandular hairs.

9- Numerous scattered cystoliths of calcium carbonate, regular in outline with warty surfaces and acute to rounded ends.

\section{THE STEM}

\section{Macromorphology}

The stem (Fig. 1A) is quadrangular, pubescent, swollen at the nodes, measuring $0.2-2.5 \mathrm{~cm}$ in diameter and about 0.5- $2 \mathrm{~m}$ in length. It is monopodially branched and shows more or less long internodes, up to $7 \mathrm{~cm}$. in the upper parts and much shorter at the base. The surface of the young shoots is hairy, green in colour, while that of the older one is brownish in colour with some raised lenticels. The stem breaks with fibrous fracture and has faint odour and slight bitter taste.

Micromorphology of the young stem

A transverse section in the young stem (Fig. 5A) appears quadrangular in outline. It shows an epidermis covered with thin cuticle carrying glandular and nonglandular hairs and having cystoliths; narrow cortex; continuous ring of vascular tissues transversed by medullary rays and central wide parenchymatous pith.

\section{Epidermis}

The epidermis, (Fig. 5C) consists of square to slightly rectangular cells measuring 13-14-15 in height. In surface view, (Fig. 6) the cells are polygonal to subrectangular with straight anticlinal walls, covered with smooth cuticle and measuring 23-3265 in length and 11-17-28 in width. Glandular and nonglandular hairs (Fig. 6) are present similar to those of the leaf. Cystoliths are abundant while stomata being rare.

\section{Cortex}

The cortex (Fig. 5A\&C) is comparatively narrow, being formed of an outer continuous layer of 6-8 rows of collenchyma measuring 5-1123 in diameter, some cells are modified to cystoliths measuring 1113-17 in diameter. The inner layer formed of several rows of cellulosic, parenchyma cells with narrow intercellular spaces measuring 8-2845 in diameter, containing starch granules, measuring 2- $\underline{3}-4$ ) in diameter, and acicular crystals of calcium oxalate measuring 3-4-7 in length. Few parenchyma cells are modified to cystoliths, while most cells adjacent to the vascular bundle contain more starch and acicular crystals of calcium oxalate than the other cells.

\section{Endodermis}

The endodermis is formed of thinwalled tangentially elongated cells containing starch granules. 


\section{Pericycle}

The pericycle, (Fig. 5C) is formed of one layer of thin-walled, nonlignified cells with narrow intercellular spaces.

\section{Vascular system}

The vascular system, (Fig. 5C) is formed of a continuous ring of phloem, xylem and cambial tissues.

\section{Phloem}

The phloem, (Fig. 5C) is formed of phloem parenchyma, sieve tubes, companion cells and phloem fibers; the phloem parenchyma are polygonal to subrectangular; the phloem fibers (Fig. 6) have moderately thick, slightly lignified walls, comparatively narrow lumine and acute apices, measuring 496-840-1200 in length and 4-11-12 in width.

\section{Cambium}

The cambium, (Fig. 5C) is formed of 2-3 rows of subrectangular, tangentially elongated, radially arranged, thin cellulosic walled cambiform cells.

\section{Xylem}

The xylem, (Fig. 5A\&C) consists of a comparatively wide zone interrupted by another narrow zone of thick-walled lignified elements. The xylem elements (Fig. 6) include lignified vessels, wood parenchyma, wood fibers, tracheids and tracheidal fibers. The vessels are lignified with pitted, spiral and sclariform thickening measuring about 14-25-38 in diameter. The wood parenchyma cells are polygonal to subrectangular in shape with lignified pitted walls and measuring about $8-\underline{13}-80$ in length and 4-10-19 in width. The tracheids are subrectangular elongated with lignified pitted walls and straight to slightly blunt ends, measuring 108-142-148 in length and 18-23-23 in width. The tracheidal fibers are elongated, having lignified walls, with fine oblique slitshape pits and acute to blunt apices, measuring 255-310-371 in length and 11-18-27 in width. The wood fibers are elongated with blunt to acute apices, wide lumina and thick lignified walls; they measure 220245-400 in length and 12-15-20 in width.

\section{Medullary rays}

The medullary rays (Figs. 5C\&6) are uni- to triseriate, radially elongated, lignified and pitted in the xylem region but with thin cellulosic walls in the phloem region.They measure about $6-\underline{13}-80$ in length, and 5-8-21 in width.

\section{Pith}

The pith (Figs. 5A,C\&6) is formed of a wide central zone of rounded to oval parenchymatous cells. The outer two rows are formed of thick-walled cellulosic cells; while the remaining has thick slightly lignified walls. The size of the cells increases towards the center reaching 17-37-58 in diameter. They contain numerous scattered acicular crystals of calcium oxalates, as well as numerous starch granules mainly of the compound type (2-4 components). 

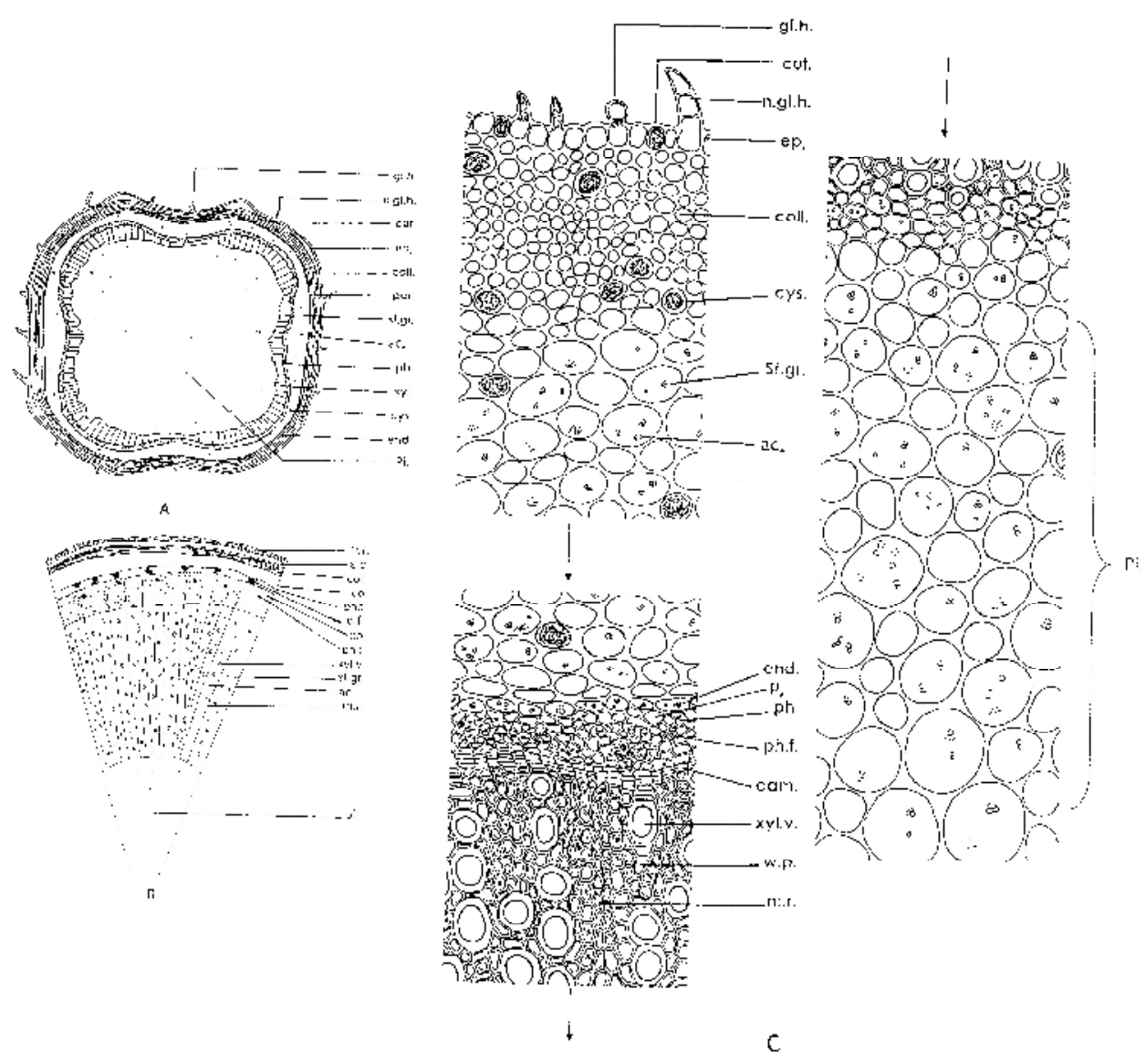

Fig. 5: Micromorphology of the stem
A) T.S. Diagram of the young stem
(x 11.2)
B) T.S. Diagram of the old stem
(x 8)
C) Detailed T.S. Sector of the young stem
(x 194)

ac., acicular crystals of calcium oxalate; cam., cambium; coll., collenchyma; co., cortex; cor., cork; cut., cuticle; cys., cystoliths of calcium carbonate; end., endodermis; ep., epidermis; gl.h., glandular hair; m.r., medullary ray; n.gl.h., nonglandular hair; par., parenchyma; p., pericycle; p.f., pericyclic fibers; ph., phloem; ph.f., phloem fibers; pi., pith; s.c., secondary cortex; st.gr., starch granules; w.p., wood parenchyma; xyl., xylem; xyl.v., xylem vessel. 
Micromorphology study of the old stem

A transverse section in the old stem (Fig. 5B) is nearly circular in outline with an outer cork layer. The phellogen originates superficially in the epidermal region. The cork in the transverse section consists of 2-3 rows of subrectangular radially arranged and tangentially elongated cells; with suberized, lignified walls and contain yellowish-brown pigments. The cork is followed by a moderately narrow secondary cortex region; a continuous layer of collenchyma cells and then by parenchyma cells. The endodermis exhibits the same features as in the young stem. The endodermis is followed by a parenchymatous pericycle with scattered batches of pericyclic fibers (absent in the young stem). The vascular bundles form a complete ring of secondary elements enclosing comparatively narrow pith. Both phloem and xylem are transversed by uni-to triseriate medullary rays.

\section{The powdered stem}

The powdered stem (Fig. 6) is yellowish green in colour, with faint characteristic odour and bitter taste. It is characterized microscopically by the following:

1- Fragments of epidermal cells, polygonal, axially elongated, with straight anticlinal walls containing cystoliths of calcium carbonate and covered with smooth cuticle.

2- Rounded to oval parenchyma cells, containing starch granules as well as acicular crystals of calcium oxalate.

3- Fragments of lignified xylem vessels showing pitted, sclariform, and spiral thickening; lignified, pitted tracheids which are subrectangular with straight to blunt apices and tracheidal fibers which are elongated with wide lumina and lignified walls with oblique slit-shape pits, in addition to lignified wood fibers with thick walls, narrow lumina and tapering ends

4- Fragments of lignified, pitted wood parenchyma and medullary rays.

5- Numerous cystoliths of calcium carbonate which are regular in outlines with warty surfaces and acute to rounded ends.

6- Fragments of slightly lignified phloem fibers, with thick walls, narrow lumina and acute to rounded apices.

7- Numerous scattered acicular crystals of calcium oxalate in addition to starch granules of different sizes, it is mainly of compound type (2-4 components), simple granules are less common.

8- Numerous scattered nonglandular and few glandular hairs which resemble those of the leaf. 


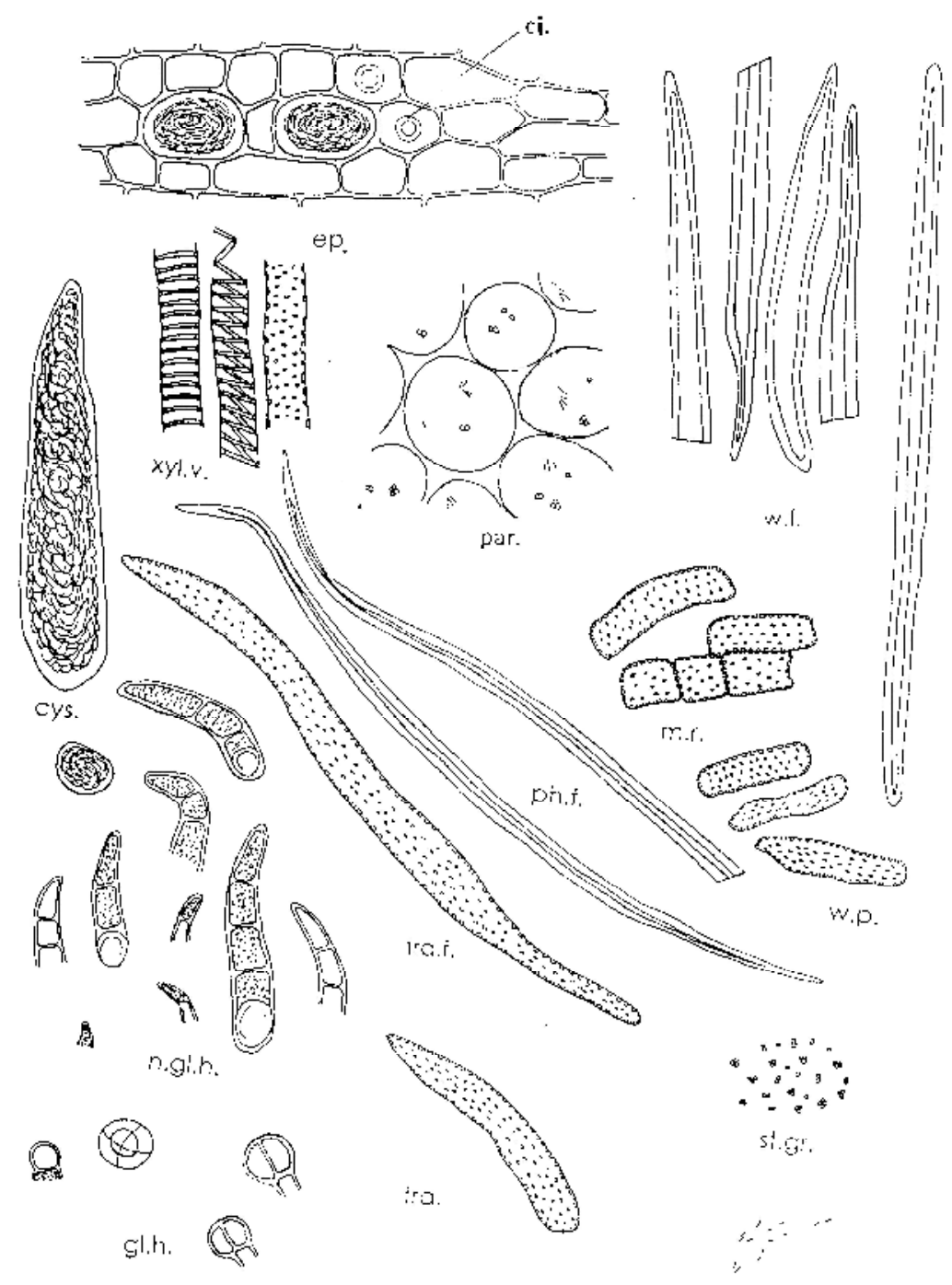

ac.

Fig. 6: Diagnostic elements of the powdered stem

(x 256)

ac., acicular crystals of calcium oxalate; ep., epidermis; ci., cicatrix; cys., cystoliths of calcium carbonate; gl.h., glandular hair; m.r., medullary ray; n.gl.h., nonglandular hair; par., parenchyma; ph.f., phloem fibers; st.gr., starch granules; tra., tracheids; tra.f., tracheidal fibers; w.f., wood fibers; w.p., wood parenchyma; xyl.v., xylem vessel. 
THE INFLORESCENCE

\section{Macromorphology}

The flowers are complete, bisexual, nearly actinomorphic to zygomorphic, arranged in terminal or axillary and opposite raceme spike inflorescence measuring $4-7 \mathrm{~cm}$ in length.

\section{The flower (Fig. 1C)}

Small, irregular, zygomorphic, hermaphrodite and sessile having the floral formula:

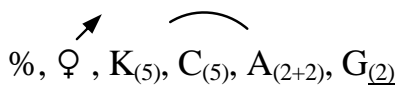

It has a faint odour and a slight bitter taste, measuring about $2.5-3 \mathrm{~cm}$ in length.

\section{Bract (Fig. 1D)}

Foliaceous, green in colour, elliptical, with acute apex, entire margin and nearly glabrous. It usually exceeds the calyx in size, measuring $1.6-2.4 \mathrm{~cm}$ in length and $0.5-1.2 \mathrm{~cm}$ in breadth.

\section{Calyx (Fig. 1E)}

White in colour, deeply divided into five lobes (including three partites, two of which split into base). The sepals measure $0.4-0.7 \mathrm{~cm}$ in length and $0.25-0.3 \mathrm{~cm}$ in breadth.

\section{Corolla (Fig. 1F)}

Violet in colour, with elongated tube which is more or less curved bearing an oblique spreading five lobed limbs. The lobes are subequal, subrounded, or obovate with rounded apices and entire margins. It measures $1-2.5 \mathrm{~cm}$ in length.

\section{Gynaecium (Figs. 1G\&10C)}

Pale green in colour formed of bicarpellary, bilocular, superior ovary, style and papillosed stigma. It has axile placentation contain two or more ovules in each locule. The ovary measures about $0.28-0.32 \mathrm{~cm}$ in length and $0.13-0.19 \mathrm{~cm}$ in diameter, while the style measures $2-2.65 \mathrm{~cm}$ in length.

\section{Androecium (Fig. 1H)}

Four epipetalous didynamous stamens inserted on the corolla tube and alternate with its lobes, arranged in two sets, two fertile with oblong two-celled anthers and two staminodes. Filaments measures 0.4$1.2 \mathrm{~cm}$ in length, while those of the staminodes are very short.

\section{Micromorphology}

\section{The bract}

A transverse section in the bract (Fig. 7A\&B) shows upper and lower epidermises, a heterogeneous mesophyll transversed by several vascular strands and small mass of collenchyma abutting on the lower epidermis.

\section{Epidermis}

The upper epidermis (Fig. 7A,B\& C) consists of polygonal cells with nearly straight anticlinal walls, while the lower epidemis consists of polygonal cells with wavy anticlinal walls and both epidermises are 

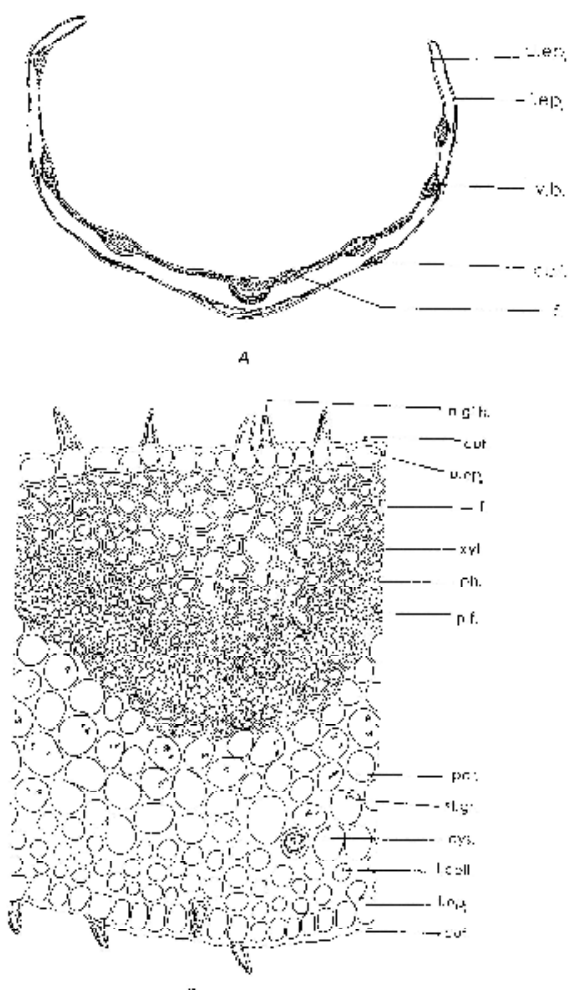

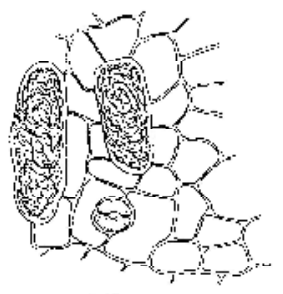

ustp

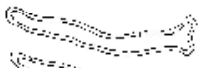

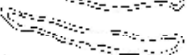

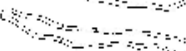

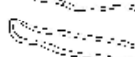

$=$

i
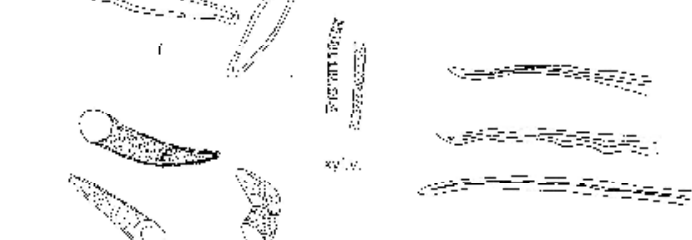

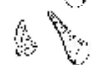
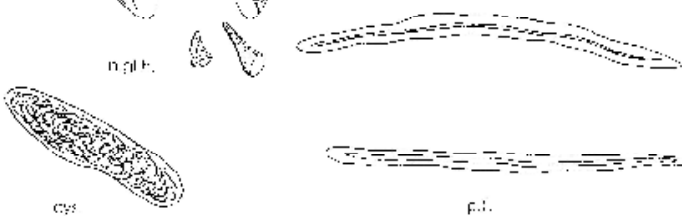

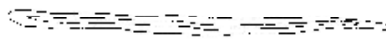

F.:.

C

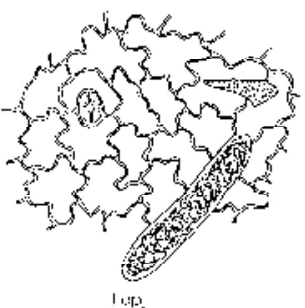

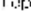

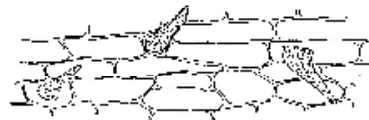

IE:...AP.
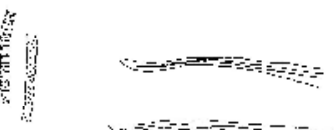

Fig. 7: Micromorphology of the bract

A) Diagramatic T.S. in the bract

B) Detailed T.S. sector in the bract

C) Diagnostic elements of the powdered bract

(x 168)

coll., collenchyma; cut., cuticle; cys., cystoliths of calcium carbonate; f., fibers; 1.coll. lower collenchyma; l.ep., lower epidermis; n.gl.h., nonglandular hair; neur.ep., neural epidermal cells; par., parenchyma; p.f., pericyclic fibers; ph., phloem; st.gr., starch granules; u.ep., upper epidermis; v.b., vascular bundles; xyl., xylem; xyl.v., xylem vessels. 
covered with smooth cuticle. The upper epidermal cells measure 27-3663 in length, 18-27-45 in width, and 11-14-18 in height; whereas the lower epidermal cells measure 43-5464 in length, 14-20-34 in width, and 12-17-23 in height. The stomta are present on both surfaces, but more abundant on the lower, of the diacytic type and measure 17-21-25 in diameter. Cystoliths are also present on both surfaces. The nonglandular hairs (Fig. 7B\&C) are present on both surfaces; unicellular and bicellular with warty cuticle measuring 25-54107 length.

\section{Cortex}

The cortex (Fig. 7A\&B) shows an upper fibrous subepidermal layer formed of several rows of fibers with thick lignified walls, measuring 6-1726 in diameter extended to the vascular tissues. The lower subepidermal cortex consists of 2-3 rows of thick walled nearly rounded collenchyma cells measuring 8-14-17

in diameter. The rest of the cortical tissue is formed of nearly rounded, thin-walled parenchyma cells, measuring 13-23-35 in diameter. It contains many starch granules, spherical to ovoid, usually compound of 2-3 components; hilum and striation being indistinguishable.

\section{Vascular tissues}

It consists of xylem and phloem elements (Fig. 7A,B\&C). The xylem consists of lignified vessels, fibers, and wood parenchyma. The vessels possess pitted and spiral thickenings, measuring 5- $\underline{8}-14$ in diameter. The phloem is formed of thin-walled cellulosic elements. The pericycle (Fig. 7B\&C) consists of continuous layer of 2-3 rows of fibers with straight thick lignified walls, narrow lumen and acute apices, measuring 202-242-291 in length and 5-11-20 in diameter.

\section{The flower}

Calyx

A transverse section in the sepals (Fig. 8A) resembles to some extent that of the bract. It comprises inner and outer epidermises, enclosing in between a heterogeneous mesophyll transveresd by numerous vascular strands. There is a small mass of collenchyma abutting on the lower epidermis and several rows of fibers abutting on the upper epidermis.

\section{Epidermis}

The epidermis of the sepals shows some variations in the cell shape and size at different regions.

\section{The inner epidermis}

In the apical region (Fig. 8D), the cells are polygonal, isodiametric with slightly wavy anticlinal walls and covered with smooth cuticle; measuring 28-38-50 in length and 8-14-17 in width. In the basal region (Fig. 8E), the cells are similar to those of the apical region, but more elongated and larger in size; the walls being nearly straight, measuring 20 34-64 in length and 7-12-19 in width. 


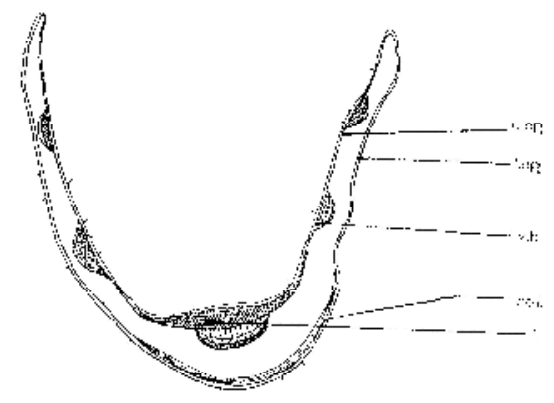

A.

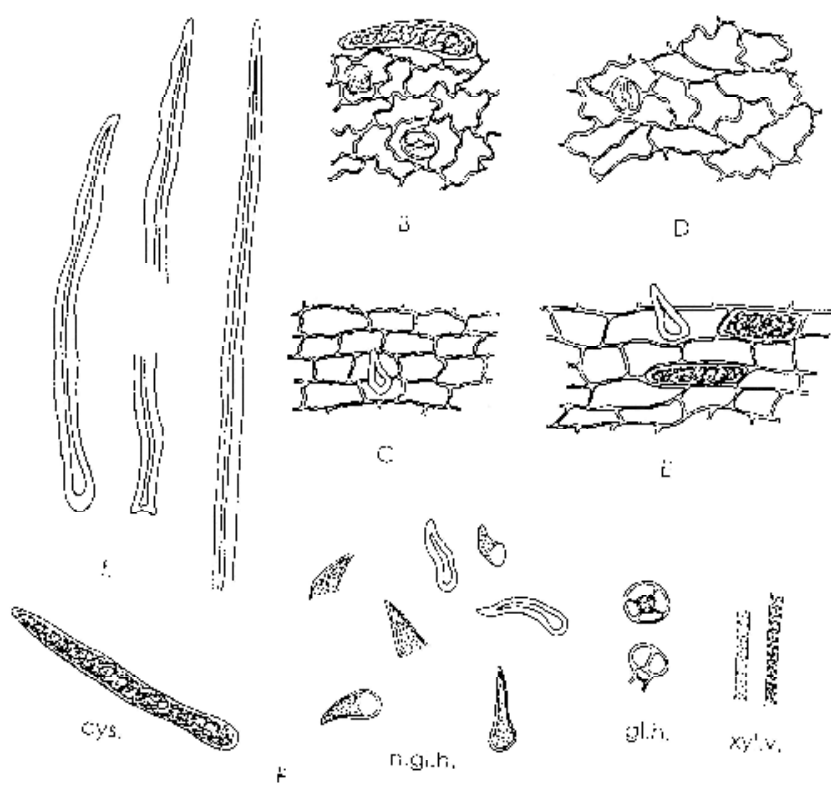

Fig. 8: Micromorphology of the caylx

A) Diagramatic T.S. of the caylx

B) Outer epidermis of the apical part of the caylx

C) Outer epidermis of the basal part of the caylx

(x 220)

D) Inner epidermis of the apical part of the caylx

(x 220)

E) Inner epidermis of the basal part of the caylx

(x 220)

F) Remaining elements of the powdered caylx

(x 220)

coll., collenchyma; cys., cystoliths of calcium carbonate; f., fibers; gl.h., glandular hair; l.ep., lower epidermis; n.gl.h., nonglandular hair; u.ep., upper epidermis; v.b., vascular bundle; xyl.v., xylem vessel. 


\section{The outer epidermis}

In the apical region (Fig. 8B), the cells are polygonal, isodiametric with wavy anticlinal walls and covered with smooth cuticle; measuring 1933-37 in length and 5-14-20 in width. In the basal region (Fig. 8C), the cells are similar to those of the apical region, but more elongated and with slightly wavy anticlinal walls; measuring 20-23-37 in length and 8-11-16 in width.

Both inner and outer epidermises show numerous cystoliths of calcium carbonate, measuring 37-53-78 in length and 9-11-15 in width.

The hairs (Fig. 8F) are glandular and nonglandular, being numerous on the outer epidermis than the inner. The nonglandular hairs are abundant and are of two types; unicellular with thick slightly lignified walls and narrow lumena, measuring 26-34-54 in length, another type is unicellular with warty cuticle measuring 25-3446 in length. The glandular hairs consist of unicellular stalk and multicellular head composed of four radiating cells, measuring 24-25-34 in length and 23-25-31 in diameter at the head of the hair.

The diacytic stomata (Fig. 8B\&D) are present on both surfaces, being more on the outer epidermis than the inner one.

\section{Corolla}

A transverse section in the petal (Fig. 9A), shows an outer and inner epidermises enclosing in between a narrow parenchymatous homogenous mesophyll transversed by several vascular strands.

\section{The inner epidermis}

In the apical part of the lip: (Fig. $9 \mathrm{E})$, the cells are polygonal with wavy to sinuous anticlinal walls and covered with smooth cuticle, measuring 28-33-39 in length and 10-17-23 in width. Stomata of diacytic type, as well as hairs are seen on the tip of the corolla. In the basal part of the lip: (Fig. 9F), the cells are more elongated, less sinuous, measuring 34-40-74 in length, and 8-12-1 in width. In the corolla style: (Fig. 9G), the cells are polygonal, axially-elongated with straight anticlinal walls and measuring 68-103140 in length and 5-14-20 in width. The hairs are very rare and the stomata are absent.

\section{The outer epidermis}

In the apical part of the lip: (Fig. 9B), the cells are similar to those of the inner epidermis, but more sinuous; measuring 30-40-60 in length and 7-15-34 in width. The hairs and stomata are more frequent than on the inner one. In the basal part of the lip: (Fig. 9C), the cells are more elongated, nearly straight, measuring $45-67-77$ in length, and 11-15-2 in width. In the corolla style: (Fig. 9D), the cells are polygonal, axially elongated with slightly wavy anticlinal walls, measuring 33-49-71 in length and 5-14-2 in width.

Hairs (Fig. 9H) are present on both surfaces; of the glandular and nonglandular types: 


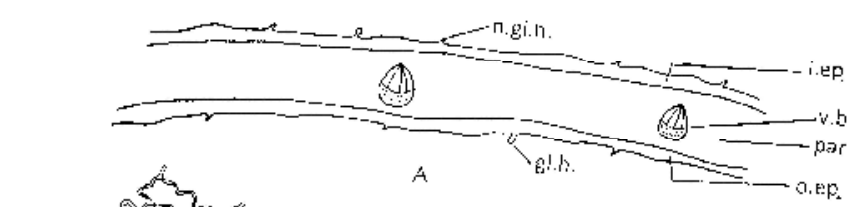

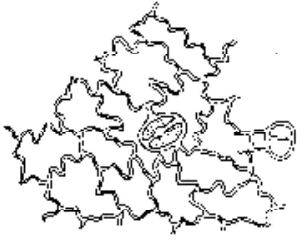

is
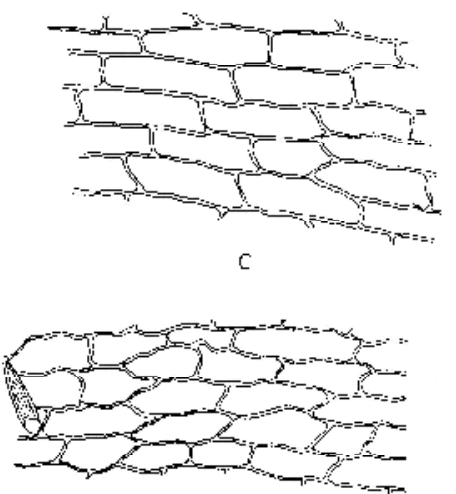

0

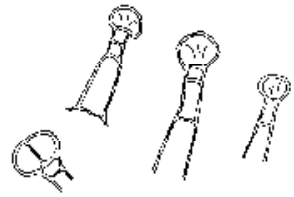

a...'-
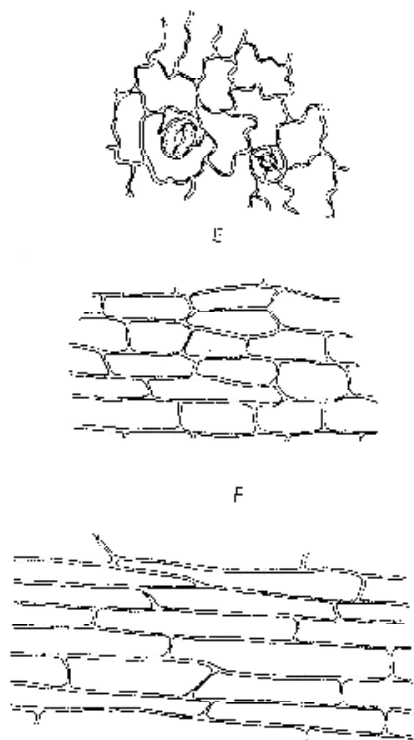

G

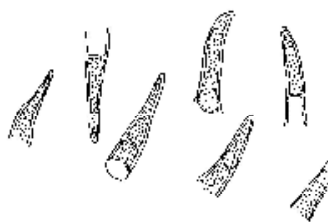

intis

Fig. 9: Micromorphology of the corolla
A) Diagramatic T.S. of the corolla
(x 76)
B) Outer epidermis of the apical part of the corolla
(x 220)
C) Outer epidermis of the basal part of the corolla
(x 220)
D) Outer epidermis of the corolla style
(x 220)
E) Inner epidermis of the apical part of the corolla
(x 220)
F) Inner epidermis of the basal part of the corolla
(x 220)
G) Inner epidermis of the corolla style
(x 220)
H) Glandular and nonglandular hairs
(x 220)

gl.h., glandular hair; i.ep., inner epidermis; n.gl.h., nonglandular hair; o.ep., outer epidermis; par., parenchyma; v.b., vascular bundles. 


\section{The glandular type}

a- Multicellular (2-3 cells) uniseriate stalk and unicellular head; measuring 51-64-85 in length and the head measuring 18-19-24 in diameter.

b- Unicellular (rarely bicellular) stalk and multicellular head of four radiating cells, measuring 32-3435 in length and the head measuring 23-25-30 in diameter.

The nonglandular hairs are unicellular and bicellular, uniseriate covered with warty cuticle, sometimes the apical cell only has warty cuticle, while the basal one being smooth measuring 44-51-67 in length.

\section{Androecium}

\section{Anther}

A transverse section in the anther (Fig. 10A) shows two lobes attached by the connective. Each anther lobe is formed of two pollen sacs, in which many pollen grains are present. The anther wall is thin, consists of an epidermis and a fibrous layer. The epidermal cells (Fig. 10B) appear polygonal in surface view with straight anticlinal walls and covered with thin smooth cuticle. They measure 11-26-33 in length and 1115-20 in width. The hairs and stomata are absent. The fibrous layer (Fig. 10A\&B) lies directly within the epidermis and consists of lignified cells with bar-like thickening, and measuring 35-57-63 in length and $16-17-28$ in width.

\section{Filament}

The epidermis of the filament (Fig. 10B) consists of polygonal cells almost axially elongated, having straight anticlinal walls and covered with smooth cuticle, measuring 6687-93 in length and 11-14-17 in width. The hairs and stomata are absent.

\section{Pollen grains}

The pollen grains (Fig. 10B) are spherical in shape, yellowish brown in colour, show reticulate exine and three germ pores and measuring 5057-85 in diameter.

\section{Gynaecium}

Ovary

A transverse section in the ovary (Fig. 10C) is more or less rounded in outline showing an epidermis enclosing parenchymatous ground tissue with two locules. Each locule has two or more ovules, two central and numerous lateral vascular strands. The epidermal cells of the ovary (Fig. 10D) are polygonal with straight anticlinal walls and covered with smooth cuticle. They measure 11- $15-$ 21 in length and 6-11-14 in width.

Stomata are absent, while the glandular hairs being numerous, with uniseriate, multicellular stalk (2-3 cells) and unicellular head measuring 40-45-54 in length and the heads measuring about 21-23 in diameter.

\section{Style}

The epidermal cells of the style (Fig. 10E) are polygonal, axially elongated cells with straight anticlinal 

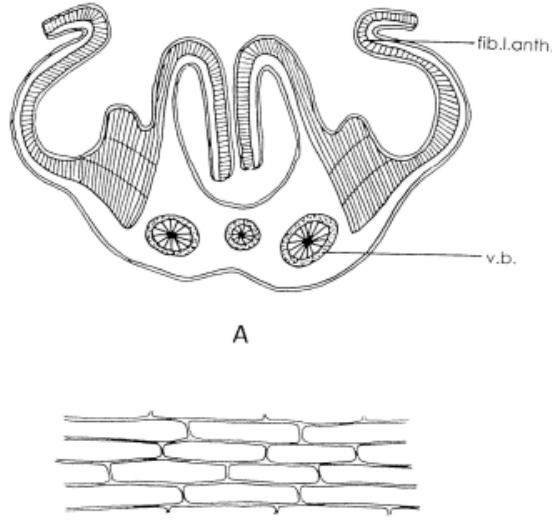

ep.tit
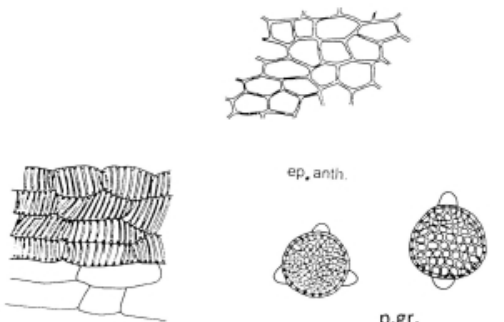

p.gr.

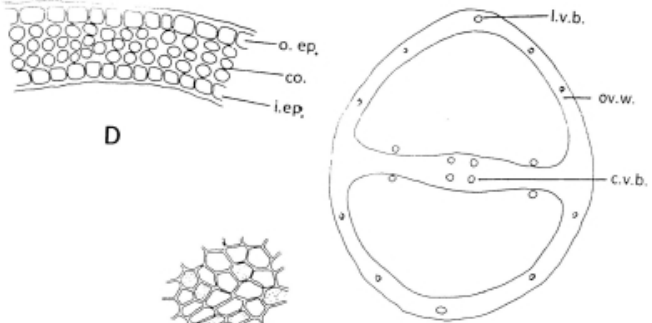

C

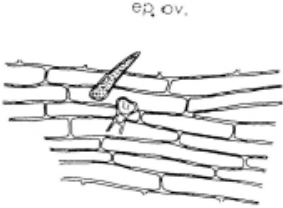

ep. sty.
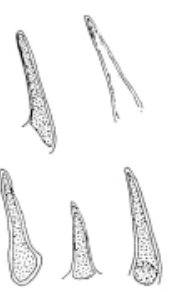

88

gi.h.

n.gl.h.

E

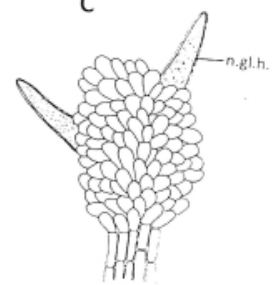

Fig. 10: Micromorphology of the flower
A) Diagramatic T.S. in the anther
(x 60)
B) Diagnostic elements of the powdered androecium
(x 168)
C) Diagramatic T.S. in the ovary
(x 41)
D) Detailed T.S. in the wall of the ovary
(x 168)
E) Diagnostic elements of the powdered gynaecium
(x 168)

C.v.b., central vascular bundles; co., cortex; ep.anth., epidermis of the anther; ep.fil., epidermis of the filament; ep.ov., epidermis of the ovary; ep.sty., epidermis of the style; f.l.., fibrous layer of the anther; gl.h., glandular hair; i.ep., inner epidermis; l.v.b., lateral vascular bundles; n.gl.h., nonglandular hair; o.ep., outer epidermis; p.st., papillosed stigma; p.gr., pollen grains; v.b., vascular bundles; ov.w., ovary wall. 
walls covered with smooth cuticle. They measure 70-82-108 in length and 7-11-14 in width. The stomata are absent, while both glandular and nonglandular hairs being present (Fig. 10E). Glandular hairs are identical to those of the corolla. Nongladular hairs are numerous and unicellular, covered with warty cuticle, rarely with smooth cuticle, measuring 5085-91 in length.

\section{Stigma}

The epidermis of the stigma (Fig. $10 \mathrm{E})$ is papillosed showing hairy papillae covered with smooth cuticle. The hairs are of the nonglandular type and are similar to those of the style.

The powder of the flower (Figs. 7C, $8,9,10 \mathrm{~B} \& 10 \mathrm{E}$ )

The powder is bluish-green in colour, with faint odour and slightly bitter taste. It is characterized microscopically by:

1- Fragments of the epidermal cells of the bract, polygonal with straight or slightly wavy anticlinal walls, covered with smooth cuticle. Few diacytic stomata as well as numerous nonglandular uni- and bicellular hairs are present.

2- Fragments of the epidermal cells of the corolla and calyx showing polygonal cells with wavy anticlinal walls, and covered with smooth cuticle. Few stomata and numerous glandular and nonglandular hairs are present.

3 - Fragments of the epidermal cells of the filament, style, and corolla style being polygonal almost axillay elongated, having straight to slightly wavy anticlinal walls and covered with smooth cuticle.

4- Fragments of papillosed sigma showing hairy papillae covered with smooth cuticle.

5- Fragments of epidermal cells of the anther being polygonal with straight anticlinal walls covered with smooth cuticle and polygonal lignified cells of the fibrous layer with bar-like thickening.

6- Numerous yellowish-brown spherical pollen grains with reticulate surface and three germ pores.

7- Fragments of the epidermis of the ovary showing polygonal, isodiametric cells with straight anticlinal walls covered with smooth cuticle.

8- Numerous scattered cystoliths containing deposits of calcium carbonate.

9- Fragments of vascular bundles showing lignified xylem vessels, with pitted and spiral thickening. Abundant wood and pericyclic fibers either entire or broken with thick lignified walls.

10-Numerous nonglandular hairs either unicellular with warty cuticle; bicellular, uniseriate with warty cuticle, sometimes the apical cell is warty while the basal one is smooth or unicellular with thick slightly lignified walls and acuminate apex.

11-Glandular hairs either multicellular (2-3 cells), uniseriate stalk and unicellular head or unicellular (rarely bicellular stalk) and multicellular four radiating celled head. 


\section{REFERENCE}

1- O. P. Sharma "Plant Taxonomy", Tata Mc Graw-Hill LTD, New Delhi (India), 1993, pp. 353-357.

2- G. H. M. Lawrence, "Taxonomy of Vascular Plants", $12^{\text {th. }}$ Printing, MacMillan Co., New York, 1968, pp. 707-709.

3- R. D. Meikle "Flora of Cyprus", Vol. II, Bentham-Moxom Trust, Royal Botanic Gardens, London, 1985, p. 1247.

4- S. M. Walters, "100 Families of Flowering Plants", $2^{\text {nd. }}$ Ed., Cambridge University Press, New York, 1991, pp. 429-432.
5- L. H. Bailey, "The Standard Cyclopedia of Horticulture", $20^{\text {th }}$ Ed., Vol. I, the MacMillan Co., New York, 1963, pp. 950-951, 1126-1127.

6- H. Fischer, W. Jensen, S. R. Jensen, and B. J. Nielsen, Phytochemistry, 26, 3353 (1987).

7- L. D. Ismail, Azhar J. Pharm. Sci., 27, 293 (2001).

8- C. R. Metcalfe and L. Chalk "Anatomy of Dicotyledons", $2^{\text {nd }}$ Ed., Clarendon Press, Oxford, 1972, pp. 1014-1022. 